\title{
TRANSPORT
}

DOI https://doi.org/10.30525/978-9934-26-046-9-49

\section{ÚSPORA ENERGIE ŽELEZNIČNÍHO VOZIDLA}

\author{
Biloshytskyi E. V. \\ Ph. D., \\ Engineer \\ Zhyzhko K. V. \\ Ph. D., \\ Director \\ Škoda Transportation Ukraine \\ Dnipro, Ukrajina
}

Je známo, že osobní doprava je jednou z hlavních činností železniční dopravy. $\mathrm{V}$ tomto př́padě je osobní kolejová vozidla důležitou součástí tohoto typu služby, což by mělo zajistit nejen bezpečnost provozu, ale také pohodlné přepravní podmínky. $\mathrm{V}$ této souvislosti úspora energie je jedním z klíčových faktorů zvyšování ziskovosti železniční dopravy. Byly stanoveny dva hlavní cíle $\mathrm{v}$ oblasti úspory energie, jmenovitě: snížení energetické náročnosti výrobních činností a zvýšení její energetické účinnosti [1].

Osobní automobily spotřebovávají významnou část elektřiny vytvářením pohodlných podmínek pro přepravu cestujících, zejména topení má významný podíl elektřriny. Přibližně $20-40 \%$ z celkové spotřeby elektřiny při přepravě cestujících slouží k vytápění, ventilaci a klimatizaci [2].

V bodech formace a obratu $\mathrm{k}$ udržení teploty v osobním vozu vyžaduje samostatný zdroj energie, $v$ jehož roli se použivá hlavně tuhé palivo. Při použití tuhých paliv, obvykle uhlí, je účinnost kombinovaného elektro-uhlí kotelu $0,40-0,65$ v závislosti na kvalitě tuhého paliva a vakua v komíně, což zvyšuje náklady na tepelnou energii pro vytápění asi o $50-60 \%$ (v závislosti na kvalitě tuhého paliva). 
Účelem této práce je zjistit možnosti zlepšení energetické účinnosti osobních automobilů, to znamená snížení spotřeby energie systémy podpory života. V současnosti je široce používán audit tepelného zobrazování kolejových vozidel. Autor následující práce [3] provedl audit tepelného zobrazování vagónů elektrických vlaků s přihlédnutím $\mathrm{k}$ řadě faktorů. Další vývoj a implementace termovizního auditu vyžaduje vypracování a zavedení energetického pasu pro každý vůz elektrického vlaku a pro elektrický vlak jako celek.

V [4] autoři popisovali procesy infiltrace vnějšího vzduchu, prosakování do auta kvůli netěsnostem ve dveřích a karoserii, což zvyšuje náklady na tepelnou energii pro udržení pohodlných podmínek $\mathrm{v}$ kolejových vozidlech. V závislosti na rychlosti vozidla, množství infiltrace při změně rychlosti z 0 na $120 \mathrm{~km} / \mathrm{h}$ dosáhne $325 \div 514 \mathrm{~m}^{3} / \mathrm{h}$, při vyšších rychlostech bude infiltrace ještě větší.

Účinek infiltrace není zkoumán $\mathrm{v}$ pracích během odstávky $\mathrm{v}$ místech vzniku a obratu cestujících vagonů, má se za to, že během parkování infiltrace chybí nebo je zanedbatelná, a proto se na ni nepřihlíží. Ve skutečnosti během provozu dochází $\mathrm{k}$ infiltračním procesům, které nejsou kryty a které zvyšují tepelné ztráty osobních vagonů.

$\mathrm{Na}$ jaře roku 2018 na základě osobních vagonů depa osobních vagony Lvov PKVCHD - 8 autor prováděl měření termální zobrazovací teplotní pole na vnější straně karoserie osobního vagonu. Pozornost byla věnována také deflektorům $\mathrm{k}$ odvádění odpadního vzduchu od sání vagony a nasávaného vzduchu ventilačního systému.

Účelem experimentálních měření bylo, stanovení míst spotřeby tepla ve vozech v důsledku působení infiltrace venkovního vzduchu při zastavení osobních vagonů, zlepšit modely tepelné bilance osobních vagonů s další úpravou konstrukčních prvků a zvýšením energetické účinnosti topných systémů.

Měření byla prováděna pomocí termokamery «Testo 875-1».№ 1991253, Rozsah měření od -20 do $100^{\circ} \mathrm{C}$; absolutní chyba měření je \pm $2 \%$ měřené hodnoty.

Experimentální měření zahrnovala měření teplotních polí vnějšku karoserie osobního vagonu, deflektory pro odvádění plného vzduchu z vůz a žaluzie venkovního vzduchu systému ventilace z obr. 1 a 2 . 


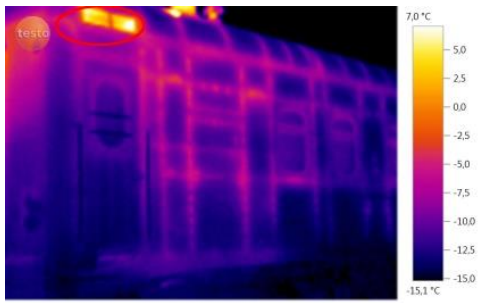

a

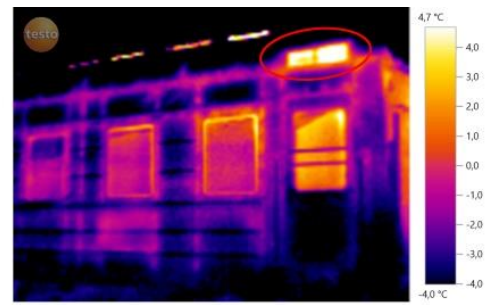

6

Obr. 1. Tepelné vzorce měření vagonu:

$a, b$-sací rolety systému ventilace venkovního vzduchu

Jak je patrné z termogramů zobrazených na obr. 1, dochází ke ztrátám tepelné energie sacími clonami ventilačního systému, zejména vzduch, který prochází vzduchovými kanály ventilačního systému, opouští vůz do okolního prostředí. Je třeba poznamenat, že situaci zhoršuje, že před vstupem do vnějšího vzduchu $\mathrm{s}$ pokojovou teplotou vůz prochází ohřívačem vody a zahřeje se na ještě vyšší teplotu.

Jak je patrné $\mathrm{z}$ termogramů zobrazených na obr. 2, přes deflektory se uvolňuje teplý vzduch, který odvádí odváděný vzduch z vůz do životního prostředí. Toto je obvykle jejich běžný provozní režim, ale jak je uvedeno $\mathrm{v}$ [5] v těle osobního vozu jsou přiděleny dvě zóny teplotních polí s různými teplotními režimy, které jsou odděleny ozdobným stropem. Zóny teplotních polí pod ozdobným stropem mají vyšší teplotu vzduchu.

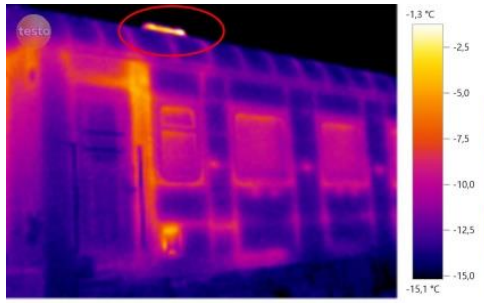

a

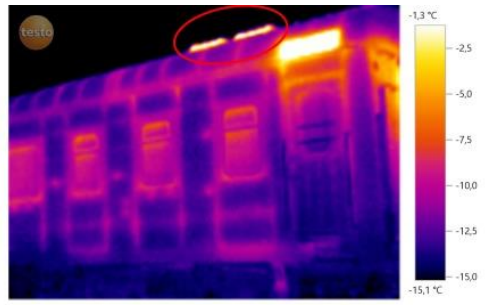

б

Obr. 2. Tepelné vzorce měření vagony:

$a, b$-deflektory pro odvod odpadního vzduchu

$\mathrm{Za}$ účelem zvýšení energetické účinnosti systémů ohřevu vody $\mathrm{k}$ eliminaci nebo snížení tepelných ztrát sacími clonami ventilačního systému autoři navrhují instalovat zpětný ventil s nízkým odporem ve vzduchovém potrubí před ohřívačem ve směru pohybu vzduchu při běžícím ventilačním 
systému. Když je tedy ventilační systém vypnutý, ventil se uzavře a zabrání tepelným ztrátám skrz sací žaluzie ventilačního systému.

S pomocí termovizních měření osobních kolejových vozidel byla detekována neproduktivní spotřeba tepla nasávacími clonami ventilačního systému $\mathrm{v}$ důsledku infiltrace venkovního vzduchu během odstávky $\mathrm{v}$ místech vzniku a obratu osobních vagon. Vzhledem k tomu, že prochází vzduch s teplotou vagon ohřivačem a zahřeje se na ještě vyšší teplotu a jde do prostředí, proto se zvyšuje spotřeba tepelné energie.

\section{References:}

1. Фалендиш А. П., Володарець М. В., Артеменко О. В. Перспективи енергозбереження для електрофікованих транспортних засобів. Вісник Східноукраӥнського національного університету імені Володимира Даля. 2017. № 4. С. 215-218.

2. Vetterli N., Menti P., Sidler F., Thaler E., Zweife G. Energy efficiency of railway vehicles. Future Buildings and Districts - Sustainability from Nano to Urban Scale: Proceedings of CISBAT 2015 International Conference, Lausanne, 9.09-11.09. 2015. Lausanne, Switzerland, 2015. P. 955-960.

3. Sumtsov A., Falendysh A., Chygyryk N., Vasilenko O., Vyhopen I. Stock. Energy Saving for the Suburban Rolling. International Journal of Engineering \& Technology. 2018. № 7. P. 361-365.

4. Ищенко В.Н., Кельрих М.Б., Брайковская Н.С., Осьмак В.Е. Теоретические основы раздельного определения показателей тепломассообмена при теплотехнических испытаниях крытых вагонов с теплоизоляцией. Збірник наукових праць Української Державної академії залізничного транспорту присвячений 60-ти річчю кафедри «Вагони». № 139. 2013. С. 35-40.

5. Білошицький Е. В. Енергоефективність систем життєзабезпечення рухомого складу залізниць. Збірник наукових праичь Украӥнського державного університету залізничного транспорту. 2018. № 179. C. 13-25. DOI: https://doi.org/10.18664/1994-7852.179.2018.147709 